\title{
Uterine secretion-like proteins in the seminal plasma of the rabbit
}

\author{
C. Kirchner and H. G. Schroer \\ Department of Biology, University of Marburg, Germany
}

\begin{abstract}
Summary. The results of polyacrylamide disc electrophoretic, gel chromatographic and agar gel immunoelectrophoretic analyses of rabbit seminal plasma were compared to those for uterine secretions and serum. Two of the seminal plasma proteins seemed to be identical with the uterine proteins uteroglobin and prealbumin.
\end{abstract}

\section{Introduction}

The male genital tract is of special interest to developmental physiologists for, apart from nourishing, mobilizing and storing spermatozoa, its glands also secrete seminal plasma which enters the vagina with the spermatozoa during mating. Several workers have studied the seminal plasma proteins of the rabbit (Weil \& Finkler, 1958; Weil \& Rodenburg, 1962; Bennett, 1965; Hunter \& Hafs, 1965; Menge \& Protzman, 1967; Hunter, 1969; Hunter \& Nornes, 1969; Symons \& Herbert, 1971; Lavon, 1972; Yantorno, Vides \& Vottero-Cima, 1972; Zappi, Smith \& Shulman, 1972; Beier \& Kühnel, 1974). The various proteins ultimately present in the seminal plasma may originate from the serum or be synthesized by the male genital tract.

In the present study, the proteins of rabbit seminal plasma were fractionated by polyacrylamide disc electrophoresis and gel filtration, and analysed by agar gel immunoelectrophoresis using polyvalent antiserum to rabbit seminal plasma.

\section{Materials and Methods}

Semen was collected from 18 rabbits of the Alaska strain and 10 of the Dwarf Chinchilla strain by means of an artificial vagina. The samples $(>150)$ were centrifuged for $15 \mathrm{~min}$ at $12,000 \mathrm{~g}$ to remove the spermatozoa. Quantitative protein determinations of the supernatant with a photometer yielded an average protein concentration of $35 \mathrm{mg} / \mathrm{ml}$. The seminal plasma was freeze-dried and stored at $-23^{\circ} \mathrm{C}$ until use. Polyacrylamide disc electrophoreses (Davis, 1964) were carried out with 4-7 $\mu \mathrm{l}$ fresh seminal plasma per column, corresponding to $150-250 \mu \mathrm{g}$ protein, depending on the staining method.

Protein staining was performed with Amido Black 10B, and carbohydrate staining with a modification (Kirchner, 1969) of the periodic acid-Schiff (PAS) reaction (Schwick, 1965). Quantitative densitometry of electrophoretic patterns was carried out with the Zeiss photometer PMQ 2 using a scanning apparatus devised by Koch (1968). Fractionations of pooled, stored seminal plasma were accomplished on a Sephadex G-75 SF column $(100 \mathrm{~cm} \times 1.5 \mathrm{~cm})$ with 0.02 M-citrate buffer, pH 9.2. Immune electrophoresis was performed with 1.5\% agar gel (Scheidegger, 1955): fresh seminal plasma or its Sephadex fractions were used for antigens and rabbit sera and flushings from a rabbit uterus 6 days $18 \mathrm{hr}$ after mating were used for comparison. Sheep antisera to rabbit seminal plasma before and after absorption with rabbit serum and rabbit uterine secretion were used as sources of antibodies. A sheep was given i.m. injections of $5 \mathrm{mg}$ dry rabbit seminal plasma proteins dissolved in $1 \mathrm{ml}$ distilled water and mixed with Freund's adjuvant on 4 consecutive days. Booster injections of $10 \mathrm{mg}$ seminal plasma proteins were given on the $7 \mathrm{th}, 14 \mathrm{th}$ and $21 \mathrm{st}$ days, and serum was collected on the 35th day. Monospecific guinea-pig anti-albumin serum, anti-transferrin serum, anti-IgG serum and anti-uteroglobin serum were used to identify individual seminal proteins which were stained with Coomassie Brilliant Blue. Each electrophoresis was repeated at least 4 times. 


\section{Results}

About 16 fractions were distinguished in the seminal plasma by polyacrylamide disc electrophoresis (Text-fig. 1). The most obvious fractions were in positions 1 (the location of uterine prealbumin), 2 (the location of albumin), and 6 (the location of transferrin). Staining with PAS showed that many seminal plasma proteins, especially that in position 1 , contain carbohydrates (Text-fig. $1 \mathrm{~b}$ ).
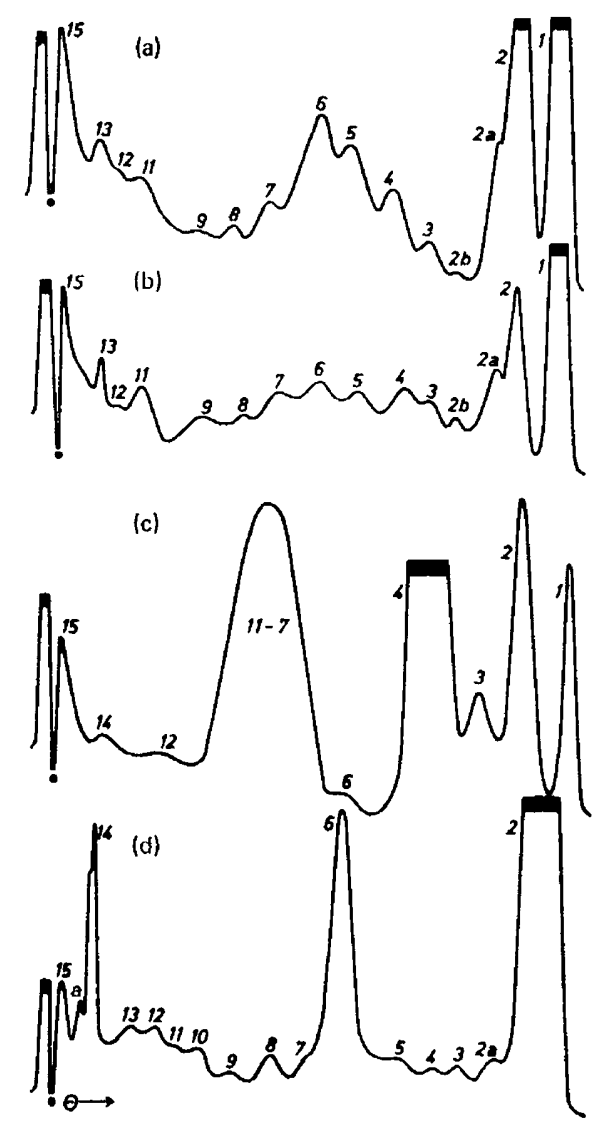

Text-fig. 1. Disc electrophoresis densitometer profiles of rabbit seminal plasma, after (a) protein staining and (b) carbohydrate staining, in comparison with (c) uterine secretion 6 days 18 hr post coitum after protein staining and (d) serum after protein staining. $\mathrm{cl}=$ uterine prealbumin; $\mathrm{c2}$ and $\mathrm{d} 2=$ albumin; $\mathrm{c} 4=$ uteroglobin; $c 6$ and $\mathrm{d} 6=$ transferrin; $\mathrm{c} 7-\mathrm{c} 11=\beta$-glycoprotein.

For the 12 possible reaction combinations (Table 1), 21 seminal plasma antigens were identified (Text-fig. 2). Twelve antigens were present only in the seminal plasma (E antigens, Text-fig. 2A and 2B); 4 were present in seminal plasma and uterine secretion (EU antigens, Text-figs 2C and 2D). We consider that antigen 2 is identical or partly identical with the uterine secretion protein, prealbumin, and that antigen 3 is partly identical with uteroglobin. Only 2 antigens were present in seminal plasma and serum (ES antigens, Text-figs $2 \mathrm{E}$ and $2 \mathrm{~J}$ ). Antigen e showed a positive lipid reaction and migrated in the agar gel to the same position as does human $\beta$-lipoprotein. Three antigens were present in seminal plasma, serum and uterine secretion (EUS antigens, Text-figs $2 \mathrm{~F}, 2 \mathrm{G}, 2 \mathrm{H}$ and $2 \mathrm{~J}$ ). Using monospecific antisera two of these antigens were identified as albumin and immunoglobulin $\mathrm{G}$, but we found no reaction in the seminal plasma with anti-transferrin serum. 
Table 1. The 12 possible reaction combinations between rabbit seminal plasma, rabbit uterine secretion and rabbit serum give precipitates of the following antigen types: $\mathrm{E}$, antigens specific for seminal plasma proteins; EU, antigens present in seminal plasma and uterine secretion; ES, antigens present in seminal plasma and serum; EUS, antigens present in seminal plasma, uterine secretion and serum

\begin{tabular}{|c|c|c|c|}
\hline & $\begin{array}{l}\text { Rabbit seminal } \\
\text { plasma }\end{array}$ & $\begin{array}{l}\text { Uterine } \\
\text { secretion }\end{array}$ & Serum \\
\hline $\begin{array}{l}\text { Anti-rabbit } \\
\text { seminal plasma }\end{array}$ & $\begin{array}{l}\text { (1) } \mathrm{E} \\
\text { EU } \\
\text { ES } \\
\text { EUS }\end{array}$ & $\begin{array}{l}\text { (5) EU } \\
\text { EUS }\end{array}$ & $\begin{array}{l}\text { (9) ES } \\
\text { EUS }\end{array}$ \\
\hline $\begin{array}{l}\text { Anti-rabbit seminal } \\
\text { plasma }+ \text { uterine secretion }\end{array}$ & $\begin{array}{l}\text { (2) } \mathrm{E} \\
\mathrm{ES}\end{array}$ & $\begin{array}{l}(6)- \\
\text { (absorption control) }\end{array}$ & (10) ES \\
\hline $\begin{array}{c}\text { Anti-rabbit seminal } \\
\text { plasma + serum }\end{array}$ & $\begin{array}{l}\text { (3) } \mathrm{E} \\
\mathrm{EU}\end{array}$ & (7) $\mathrm{EU}$ & $\begin{array}{c}\text { (11) - } \\
\text { (absorption control) }\end{array}$ \\
\hline $\begin{array}{c}\text { Anti-rabbit seminal } \\
\text { plasma }+ \text { uterine } \\
\text { secretion }+ \text { serum }\end{array}$ & (4) $\mathrm{E}$ & $\begin{array}{l}(8)- \\
\text { (absorption control) }\end{array}$ & $\begin{array}{c}(12)- \\
\text { (absorption control) }\end{array}$ \\
\hline
\end{tabular}

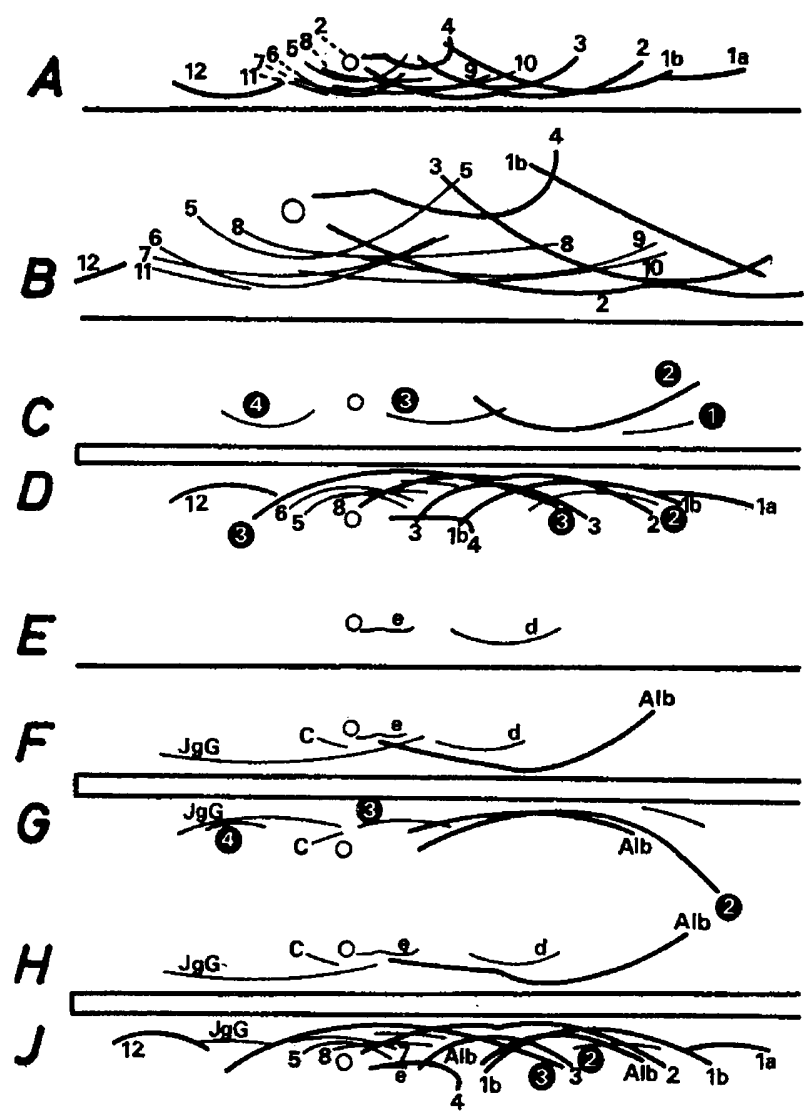

Text-fig. 2. Diagram of the immune electrophoresis results of the combinations shown in Table 1 for classification of the 4 types of rabbit seminal plasma antigens. $A=$ combination $4 ; B=$ higher magnification of $\mathrm{A} ; \mathrm{C}=$ combination $7 ; \mathrm{D}=$ combination $3 ; \mathrm{E}=$ combination $10 ; \mathrm{F}$ and $\mathrm{H}=$ combination 9 ; $\mathrm{G}=$ combination $5 ; \mathrm{I}=$ combination 1 . Black numbers = precipitates of the $\mathrm{E}$ antigens; white numbers = EU antigens; small letters = ES antigens; large letters = EUS antigens. 
A typical-Sephadex G-75 SF elution profile of seminal plasma shows 6-7 peaks in a series of decreasing molecular weights (Text-fig. 3). Disc electrophoreses and immune electrophoretic analyses of the eluted samples 16-28 (Text-fig. 4) showed that most of the seminal plasma proteins were distributed in the area of medium electrophoretic mobility, as are those of uterine secretions (Kirchner, 1969) but not those of serum. Like uterine prealbumin and uteroglobin, 3 of the 4 EU-type proteins were included in the area of medium- to small-sized proteins: EU 2 was present in Fractions 21-24, EU 3 in Fractions 21-28 and EU 4 in Fractions 21-22.

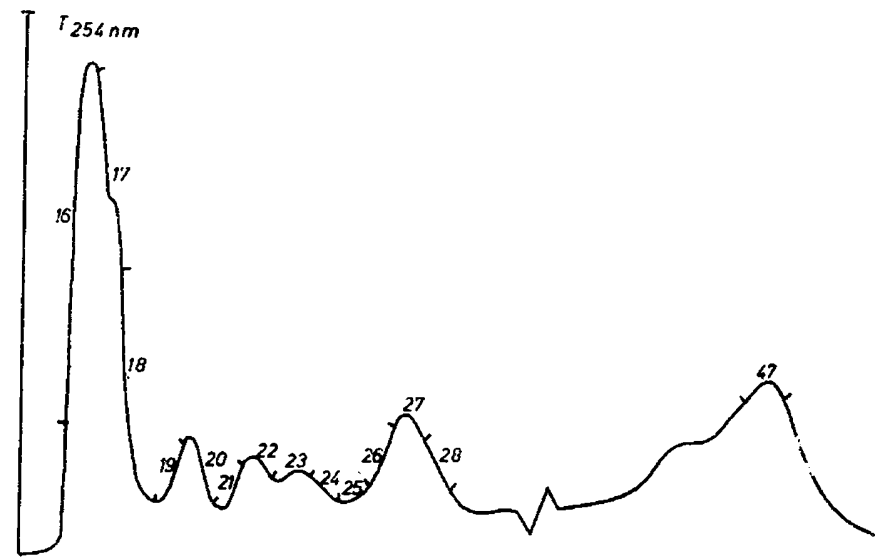

Text-fig. 3. Elution diagram of rabbit seminal plasma gel filtration through Sephadex G-75 SF to give protein Fractions 16-28.

Further study with gel chromatography, disc electrophoresis and immune electrophoresis confirmed that seminal plasma protein EU 2 corresponds in molecular size, electrophoretic mobility in two systems and carbohydrate content to the uterine-specific prealbumin. The precipitate of the cross-reaction of uterine secretion with antiserum to seminal plasma is so heavy that both proteins are either identical or contain several identical immunogenic regions. The seminal plasma protein EU 3 corresponds in molecular size and electrophoretic mobility to uteroglobin, as shown by the similarity in the precipitates (Text-fig. 5). Precipitates were also found in cross-reactions of uterine secretion or purified uteroglobin with antiserum to seminal plasma and in the reactions of seminal plasma with monospecific anti-uteroglobin serum. Both, however, were much weaker and showed slight differences in position; serum-absorbed anti-seminal plasma serum and uterine secretion (Textfig. 2C) formed a precipitate which was shifted a few millimetres from the starting point towards the anode. The precipitate of seminal plasma with monospecific anti-uteroglobin serum, however, was positioned directly beneath the starting point, as were the two homologous precipitates shown in Text-fig. 5 .

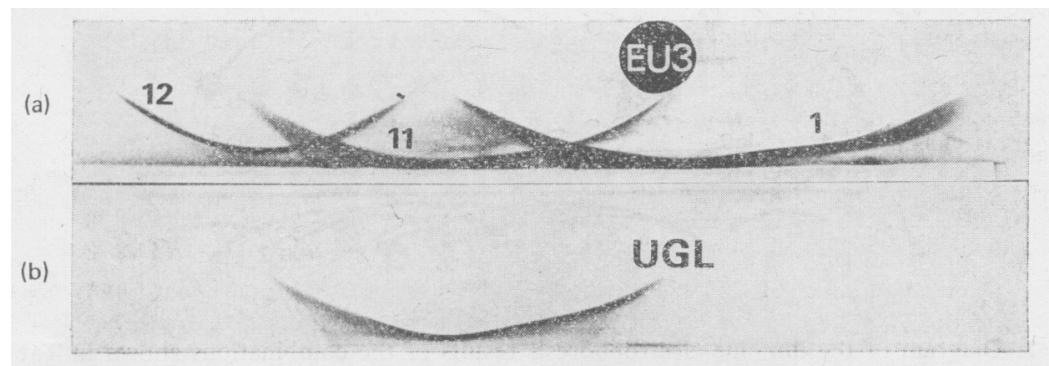

Text-fig. 5. Immune electrophoreses of Fraction 26 with sheep anti-rabbit seminal plasma serum (a) and of uterine secretion with monospecific guinea-pig anti-uteroglobin serum (b), illustrating the similar electrophoretic mobilities and precipitation forms of the seminal plasma protein, EU 3, and the uterine secretion protein, uteroglobin. 


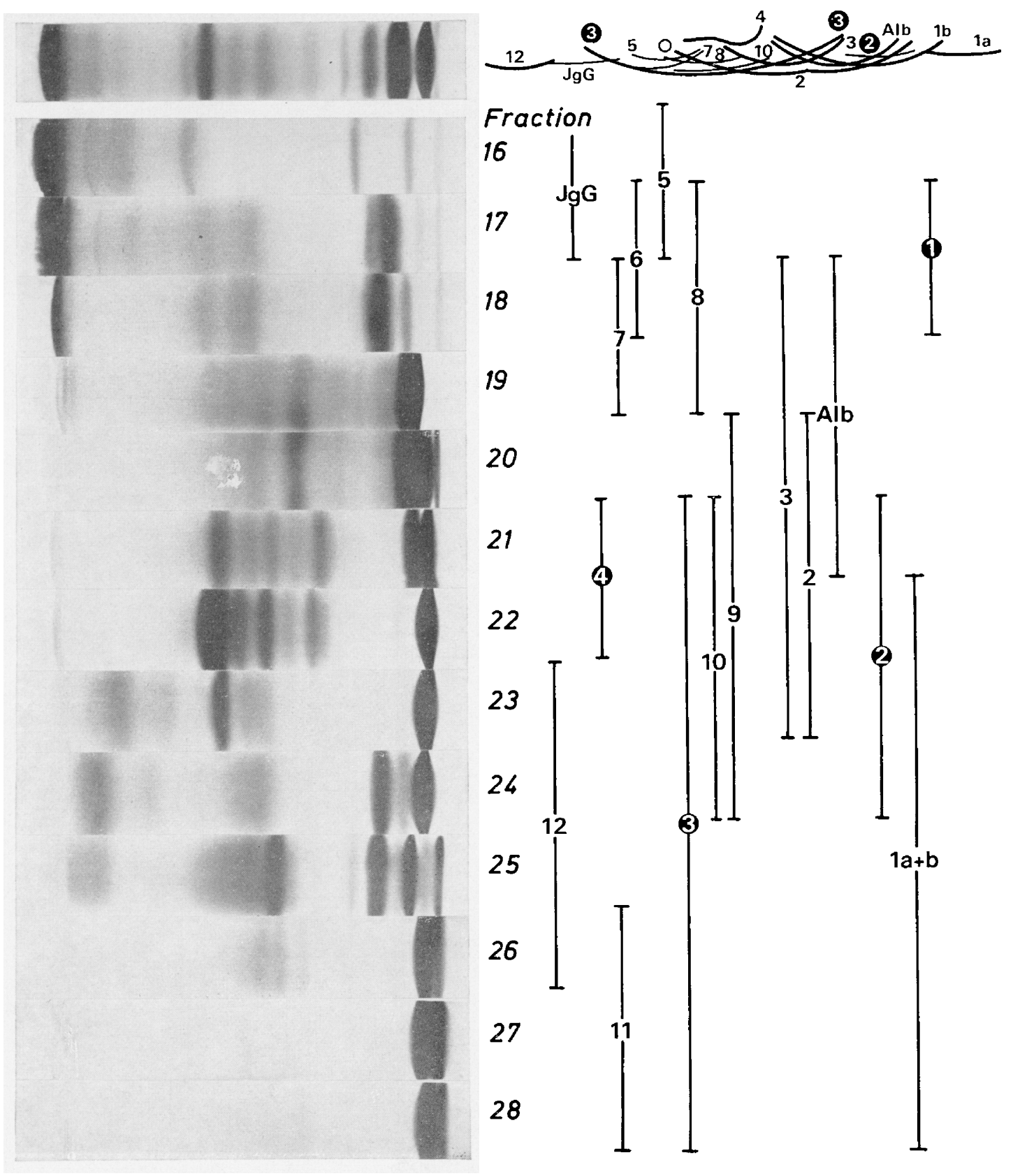

Text-fig. 4. Disc electrophoreses of rabbit seminal plasma and Fractions 16-28 of the gel filtration combined with the results of the immune electrophoretic analyses. 


\section{Discussion}

The 6 discrete peaks demonstrated for rabbit seminal plasma with Sephadex G-75 SF (Text-fig. 3) were similar to those obtained by Yantorno et al. (1972) with Sephadex G-100, and by Zappi et al. (1972), who compared the filtration capabilities of G-50, G-100 and G-200. Immune electrophoreses (Text-fig. 4), however, showed that many of the seminal plasma proteins are distributed over the area of 2 or more peaks, and more refined techniques than gel filtration must be used to isolate single proteins. Using sheep for immunization with rabbit seminal plasma proteins, Yantorno et al. (1972) obtained 14 precipitates by means of an Ouchterlony test of Sephadex fractions, but the 21 precipitates we obtained could probably be increased in number if single fractions were used for immunization instead of whole seminal plasma. Albumin and IgG have been reported previously in rabbit seminal plasma (Symons \& Herbert, 1971; Ablin, 1972), as has transferrin (Beier \& Kühnel, 1974), but we found no evidence that transferrin is a component of seminal plasma.

The most striking findings of the present study are the similarities of the physical, chemical and immunological characteristics of the seminal plasma proteins, EU2 and EU3, with the uterine secretion proteins, prealbumin and uteroglobin. This confirms suggestions that uteroglobin or a very similar protein is synthesized by the seminal vesicles (Beier \& Kühnel, 1974). Further attempts will be made to determine to what extent prealbumin and uteroglobin are comparable with these seminal plasma proteins. The existence, however, of two low molecular-weight proteins in seminal plasma and uterine secretions in pregnancy suggests that these proteins could have important functions in aiding sperm viability or the viability of germ cells in general (Yoshinaga \& Stocker, 1972).

This work was supported by Grant Ki 154/5-6 from the Deutsche Forschungsgemeinschaft.

\section{References}

Ablin, R.J. (1972) Distribution of rabbit IgG in the accessory sexual gland tissues of the male rabbit. J. Reprod. Fert. 30, 201-205.

Beier, H.M. \& Kühnel, W. (1974) Morphologische und biochemische Untersuchungen der Sekretion von Samenblasen. Verh. anat. Ges., Jena 68, 231-245.

BenNeTT, J.P. (1965) Quantitative comparisons of the proteins of seminal plasma of bull, ram, rabbit and boar by agar gel electrophoresis. J. Reprod. Fert. 9, 217-231.

DAvis, B.J. (1964) Disc electrophoresis. II. Method and application to human serum proteins. Ann. N.Y. Acad. Sci. 121, 404-427.

HunTer, A.G. (1969) Differentiation of rabbit sperm antigens from those of seminal plasma. J. Reprod. Fert. 20, 413-418.

Hunter, A.G. \& Hafs, H.D. (1965) Differentiation of sperm protein from that of seminal plasma in rabbits. Fedn Proc. Fedn Am. Socs. exp. Biol. 24, 700, Abstr. No. 3159.

Hunter, A.G. \& Nornes, J. (1969) Characterization and isolation of a sperm-coating antigen from rabbit seminal plasma with capacity to block fertilization. J. Reprod. Fert. 20, 419-427.

KIRCHNER, C. (1969) Untersuchungen an uterusspezifischen Glykoproteinen während der frühen Gravidität des Kaninchens Oryctolagus cuniculus. Wilhelm Roux Arch. EntwMech. 164, 97-133.

Koch, P. (1968) Disc-Elektrophorese: Ein Photometerzusatz zur Auswertung von Gelsäulen. Zeiss Mitt. Fortschr. tech. Opt. 4, 397-403.
LAvon, U. (1972) Characterization of boar, bull, ram and rabbits seminal plasma proteins by gel disc electrophoresis and isoelectric focusing on polyacrylamide. J. Reprod. Fert. 31, 29-37.

Menge, A.C. \& Protzman, W.P. (1967) Origin of the antigens in rabbit semen which induce antifertility antibodies. J. Reprod. Fert. 13, 31-40.

SCheidegger, J.J. (1955) Une micro-methode de l'immunoélectrophorèse. Int. Archs Allergy appl. Immun. 7, 103-110.

SchwICK, H.G. (1965) Chemisch-entwicklungsphysiologische Beziehungen von Uterus zu Blastocyste des Kaninchens. Wilhelm Roux Arch. EntwMech. 156, $283-345$.

Symons, D.B.A. \& Herbert, J. (1971) Incidence of immunoglobulins in fluids of the rabbit genital tracts and the distribution of $1 \mathrm{gG}$-globulin in the tissues of the female tract. J. Reprod. Fert. 24, 55-62.

WeIL, A.J. \& Finkler, A.E. (1958) Antigens of rabbit semen. Proc. Soc. exp. Biol. Med. 98, 794799.

WeIl, A.J. \& Rodenburg, J.M. (1962) The seminal vesicle as the source of spermatozoa-coating antigens of seminal plasma. Proc. Soc. exp. Biol. Med. 109, 567-570.

Yantorno, C., Vides, M.A. \& Vottero-Cima, E. (1972) Studies of the macromolecular and antigenic composition of rabbit seminal plasma. J. Reprod. Fert. 29, 229-238.

Yoshinaga, K. \& Stocker, J.F. (1972) Fate of the 
blastocysts in the seminal vesicle of the rabbit under various hormonal conditions. Proc. 7th Int. Congr. Anim. Reprod. \& A.I., Munich, Vol. I. pp. 518523.
ZapPi, E., Smith, D.J. \& Shulman, S. (1972) Preparative separation of rabbit seminal plasma and immunochemical study of the resulting fractions. Int. J. Fert. 17, 145-152.

Received 3 February 1976 